\title{
The Blended Learning Model: Does It Work?
}

Eman Mohammed Abdel-Haq

Faculty of Education, Benha University

DOI:

\begin{abstract}
The advances in information and communicate on technologies have led to the development of wide spectrum of new techniques, methods and models of education. One of these promising approaches in education is blended learning. Although the blended learning model is not new, it produces new kinds of learning experiences and encompasses a much richer set of learning strategies or "dimensions."It maximizes the benefits of traditional and electronic delivery platforms, while diminishing the weaknesses of each. The aim of the present paper is to provide practitioners and researchers with a comprehensive framework outlining its basic characteristics and the rationale for adopting it. It also presents a multi-stage process model of it to identify the activities, actors, and key success factors associated with how best to set it up. It also outlines framework for how to evaluate the different interventions aiming at developing it.
\end{abstract}

\section{Introduction}

The main goal of educational activities is to make individuals creative, productive, with problem solving skills, and able to produce new products as they learn. Innovations in the Internet and information technologies offer individuals the opportunity to access information, to present and disseminate them cheaply and easily (Kayalar, 2020). These advances in information and communication technologies have led to the development of wide spectrum including new techniques, methods and models of education. One of the promising approaches with reference to the implementation of the digital technologies in education is blended learning (Titov, Kurilov, Titova \& Brikoshina, 2019).

Although the blended learning model is not new, it produces new kinds of learning experiences as it continues to evolve and mature. Blended learning can be defined as combining face to face education and internet/mobile. However, blended learning includes not only digitally mediated methods, offline or online, but also new non-computer educational tools and techniques (Kayalar, 2020). However, the term has evolved to encompass a much richer set of learning strategies or "dimensions". Today a blended learning program 
may combine one or more of the following dimensions, although many of these have overlapping attributes (Kayalar, 2020; Marunić, 2015; Singh, 2003).

- Mixing or combining different forms of webbased technology for an educational purpose such as virtual classrooms, self-education, learning together, video, audio or text.

- Combining different educational approaches such as a structuralist, behavioral, and cognitive approach to provide the best learning outcomes, with or without educational technology.

- Combining different educational technologies such as videotape, CD-ROM, web-based education and films with face to face instructorguided applications.

- Mixing or combining educational technology with current tasks to create a harmonious effect between learning and study.

- Blending Offline and Online Learning.

- Blending Self-Paced and Live, Collaborative Learning.

- Blending Structured and Unstructured Learning

- Blending Custom Content with Off-the-Shelf Content.

- Blending Learning, Practice and Performance Support.

Blending learning can maximize the benefits of both delivery platforms, while diminishing the weaknesses of each. It retains the potential for the immediate feedback that learners value while enabling greater participation on the part of learners who require more flexible schedules. Moreover, it enhances faculty's ability to be innovative, utilizing interactive learning activities and assignments and facilitating discussion on a variety of themes using resources from multiple partner centers and national resources. It offers increased opportunities for learners to reflect upon course concepts and share knowledge on a communal level (Lotrecchiano, McDonald, Lyons, Long \& ZajicekFarber, 2013).

Kachmarchyk, Khrystiuk and Shanaieva-Tsymbal (2019) and Titov, et al. (2019) distinguish the following benefits:

- Accessibility, flexibility, convenience, effective use of time.

- increasing the educational efficiency and students' personal motivation, autonomy, social activity;

- The possibility to vary the learning componential elements.

- Combining different training activities, the use of two or more different teaching methods, interactivity.

- Use of various techniques and approaches.

- Applying the teachers' control and students' self-control concepts.

- Efficient feedback.

- Improving the teacher - student communication and interaction quality. 
- Students' self-organizing in terms of planning their own educational activities, aimed at the outcome, identifying their own educational abilities, needs, interests, individualization of the learning process.

Alammary (2019) identified five different blended learning components which are:

- Face-to-face instructor-led.

- Face-to-face collaboration

- Online instructor-led

- Online collaboration

- Online self-paced educational approach

The development of blended learning may occur at different four organizational levels: activity level, course level, program level, and institutional level.
Blended learning is defined as a big concept that comprises four models of blended learning (Figure 1). Rotation Model and Flex Model are accomplished predominately on brick-and mortar location, while A La Carte Model and Enriched Virtual Model represent entirely online learning. Starting from four models, the first one Rotation Model is subdivided into additional four models: Station Rotation, Lab Rotation, Flipped Classroom, and Individual Rotation (Marunić, 2015).

The detailed comparison of each of these four major models in the blended learning classroom is discussed in Table 1 below (Ayob, Abd Halim, Zulkifli, Zaid\&Mokhtar, 2020).

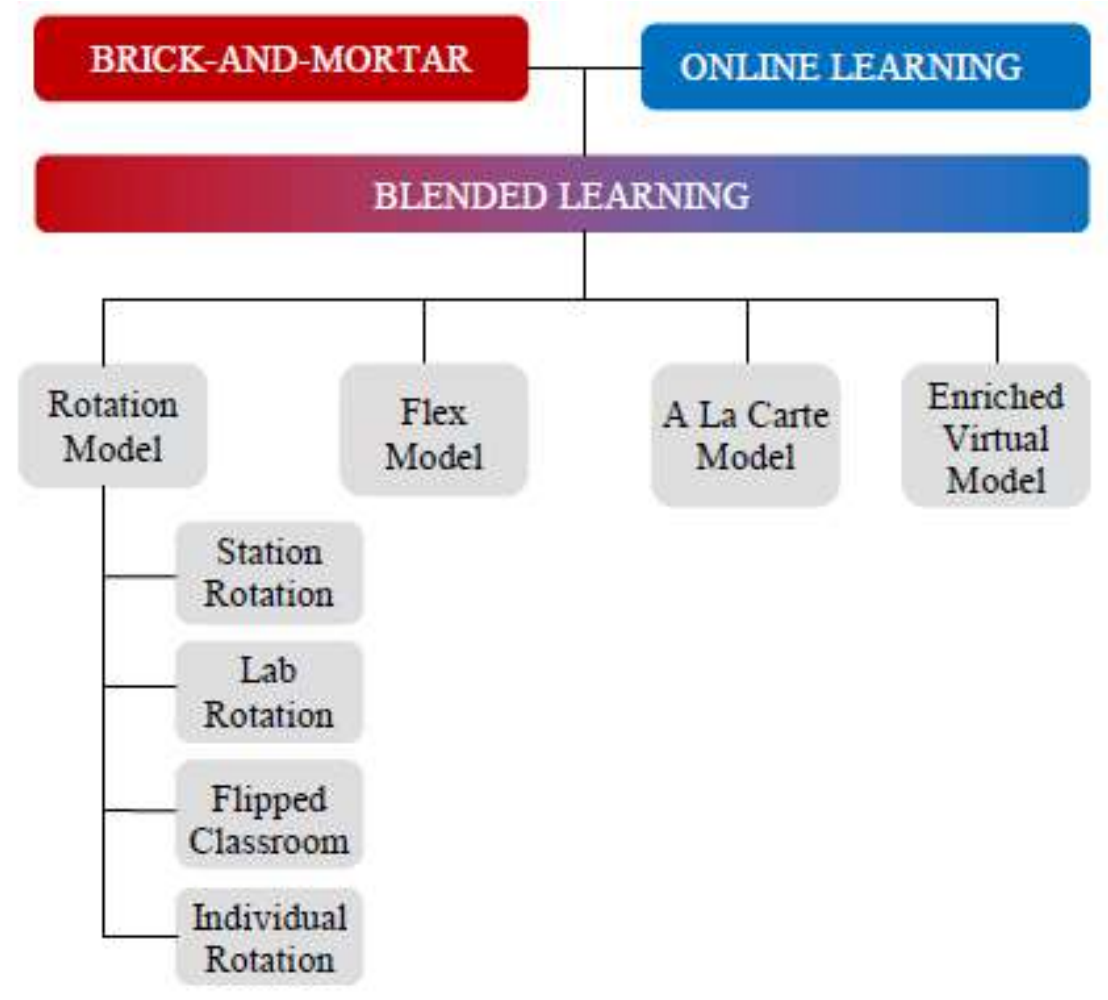

Figure (1) Models of the blended learning, adopted from Marunić, 2015, p. 62. 
Table (1) Four Major Types of Models in Blended Learning Classroom, adopted from Ayob,et al. 2020, p. 322

\begin{tabular}{|c|c|c|c|c|}
\hline Characteristics & Rotation model & Flex model & Self-blend model & $\begin{array}{l}\text { Enriched-virtual } \\
\text { Model }\end{array}$ \\
\hline Setting & $\begin{array}{l}\text { Within a classroom or a set of } \\
\text { classrooms [12], [23], [25]. }\end{array}$ & $\begin{array}{l}\text { Learning online individually } \\
\text { and learning at schools with a } \\
\text { F2F teacher. } \\
\text { Students learn mostly at } \\
\text { school with a teacher using } \\
\text { offline traditional F2F } \\
\text { learning except for the } \\
\text { homework [25]. }\end{array}$ & $\begin{array}{l}\text { Different from the } \\
\text { enriched-virtual } \\
\text { model because it is } \\
\text { not a whole-school } \\
\text { experience [23]. }\end{array}$ & $\begin{array}{l}\text { Whole school } \\
\text { experience [23]. }\end{array}$ \\
\hline Rotation & $\begin{array}{l}\text { Students rotate in a fixed } \\
\text { schedule or according to the } \\
\text { teachers' desires [12], [23], } \\
\text { [25]. }\end{array}$ & $\begin{array}{l}\text { The content and instruction } \\
\text { are fully delivered via online } \\
\text { learning } \\
\text { Backbone of this model is } \\
\text { online learning [25]. }\end{array}$ & $\begin{array}{l}\text { Students can choose } \\
\text { fully online methods } \\
\text { to support their } \\
\text { offline traditional } \\
\text { F2F learning [23]. }\end{array}$ & $\begin{array}{l}\text { Students divide their } \\
\text { time between offline } \\
\text { traditional F2F } \\
\text { learning and content } \\
\text { delivery via remote } \\
\text { online learning [23]. }\end{array}$ \\
\hline $\begin{array}{l}\text { Learning } \\
\text { method }\end{array}$ & $\begin{array}{l}\text { Students rotate among } \\
\text { stations. } \\
\text { At least one station is an } \\
\text { online learning station [23]. }\end{array}$ & $\begin{array}{l}\text { Students rotate individually } \\
\text { among learning activities and } \\
\text { offline traditional F2F } \\
\text { teachers [23]. }\end{array}$ & $\begin{array}{l}\text { Students can take } \\
\text { online learning at } \\
\text { school or home [23]. }\end{array}$ & $\begin{array}{l}\text { It usually starts with a } \\
\text { fully online learning } \\
\text { method, then becomes } \\
\text { a blended learning } \\
\text { method [23]. }\end{array}$ \\
\hline Activities & $\begin{array}{l}\text { The stations include direct } \\
\text { instruction from the teacher, } \\
\text { small group or whole class } \\
\text { activities, group projects, } \\
\text { individual tutoring and } \\
\text { assignments [23], [25]. } \\
\text { When the time is up, the } \\
\text { teacher makes an } \\
\text { announcement and instructs } \\
\text { the students to rotate and go } \\
\text { to the next activity at the next } \\
\text { station [25]. }\end{array}$ & $\begin{array}{l}\text { Offline traditional F2F } \\
\text { teacher will provide activities } \\
\text { if needed - small group, } \\
\text { group projects and individual } \\
\text { tutoring [23]. } \\
\text { Some have F2F teachers with } \\
\text { the support of online } \\
\text { learning, while some have } \\
\text { only a little offline traditional } \\
\text { F2F learning. They have } \\
\text { different combinations too } \\
\text { [23]. }\end{array}$ & $\begin{array}{l}\text { Students use online } \\
\text { learning for some } \\
\text { subjects and use } \\
\text { offline traditional } \\
\text { F2F learning for } \\
\text { other subjects [25]. }\end{array}$ & $\begin{array}{l}\text { Students seldom meet } \\
\text { F2F with their } \\
\text { teachers every school } \\
\text { day. It only happens } \\
\text { when needed [25]. }\end{array}$ \\
\hline Station & $\begin{array}{l}\text { Rotations have been used in } \\
\text { many years, but what makes } \\
\text { this blended learning is the } \\
\text { involvement of online } \\
\text { learning [12]. }\end{array}$ & $\begin{array}{l}\text { Some of them have more } \\
\text { offline traditional F2F } \\
\text { learning support, but others } \\
\text { have minimum support for } \\
\text { the traditional approach [23]. }\end{array}$ & $\begin{array}{l}\text { Students involve } \\
\text { themselves in both } \\
\text { online learning and } \\
\text { offline traditional } \\
\text { F2F learning [23]. }\end{array}$ & $\begin{array}{l}\text { Students will have } \\
\text { F2F learning with } \\
\text { their teacher and they } \\
\text { are free to complete } \\
\text { remaining works } \\
\text { remotely [25]. }\end{array}$ \\
\hline
\end{tabular}

Within the rotation model, there are four specific types which are station rotation, lab rotation, flipped classroom model and individual rotation model. Each specific type of rotation model is a little bit different from others; however, they are required to have at least one station which includes an online learning method. The table 2 below summarizes the four specific types of rotation models in a blended learning classroom.

Transitioning from a traditional $\mathrm{f} 2 \mathrm{f}$ program to a blended model with graduate-level coursework certainly produced challenges. Rasheed, Kamsinand Abdullah (2020) identified taxonomy of these challenges categorizing them into three main categories: students, teachers and institutions (Table 3, 4, 5). 
Table (2) Four Specific Types of Rotation Model in a Blended Learning Classroom, adopted from Ayob,et al. 2020, p. 323

\begin{tabular}{|c|c|c|c|c|}
\hline Characteristics & Station rotation model & Lab rotation model & Flipped classroom model & $\begin{array}{l}\text { Individual rotation } \\
\text { model }\end{array}$ \\
\hline $\begin{array}{l}\text { Learning } \\
\text { method }\end{array}$ & $\begin{array}{l}\text { Students rotate in a fixed } \\
\text { schedulc according to the } \\
\text { teachers' desires within a } \\
\text { classronm or a set of } \\
\text { classrooms [25][12]. [28] }\end{array}$ & $\begin{array}{l}\begin{array}{l}\text { Students rotate in a fixed } \\
\text { schedule according to } \\
\text { teachers desires among } \\
\text { locations in the school [28]. }\end{array} \\
\text { At least one station is } \\
\text { predominantly an online } \\
\text { learning station in a computer } \\
\text { lab [28]. } \\
\text { Students rotate in computer } \\
\text { lab for online learning [25]. }\end{array}$ & $\begin{array}{l}\text { Students rotate in a flxed } \\
\text { schedule between offline } \\
\text { traditional F2F learning } \\
\text { or projects in school and } \\
\text { contcnt dclivcry using } \\
\text { online learning after } \\
\text { schnol time } \\
\text { independently [28]. Time } \\
\text { in classes is used to } \\
\text { discuss the concepts } \\
\text { learned [12]. } \\
\text { The primary delivery of } \\
\text { content and instruction } \\
\text { from the teacher is } \\
\text { delivered during online } \\
\text { learning outside the } \\
\text { school [25], [28] }\end{array}$ & $\begin{array}{l}\text { At lcast one station is } \\
\text { an online learning } \\
\text { station [28] }\end{array}$ \\
\hline Activities & $\begin{array}{lr}\text { Other stations: small } \\
\text { group or whole class } \\
\text { activities, projects in } \\
\text { groups, } \\
\text { intoring, } \\
\begin{array}{l}\text { individual online } \\
\text { assignments, }\end{array} \\
\begin{array}{l}\text { independent work at } \\
\text { students' desks. direct }\end{array} \\
\begin{array}{l}\text { instruction from a } \\
\text { teacher [28] }\end{array}\end{array}$ & $\begin{array}{l}\text { Students rotate among } \\
\text { different locations in the } \\
\text { school instead of rotate in one } \\
\text { classroom [28] }\end{array}$ & $\begin{array}{l}\text { Students need to do } \\
\text { homework online at } \\
\text { night [25], [28]. }\end{array}$ & $\begin{array}{l}\text { Teachers will set } \\
\text { student's schedules } \\
\text { individually } \\
\text { [25]. }\end{array}$ \\
\hline Setting & $\begin{array}{l}\text { Students rotate in } \\
\text { different stations in one } \\
\text { classroom [25]. }\end{array}$ & $\begin{array}{l}\text { Very similar to station } \\
\text { rotation; the lab will be frec up } \\
\text { for other activities within the } \\
\text { rotation model [12]. }\end{array}$ & $\begin{array}{l}\text { Example: sludenls use } \\
\text { the internet to watch } \\
\text { online videos for } 1015 \\
\text { minutes and complete } \\
\text { questions on Moodle } \\
\text { [?.8]. }\end{array}$ & $\begin{array}{l}\text { Example: students } \\
\text { are given a specific } \\
\text { schedule to rotate } \\
\text { between } \\
\text { learning and offline } \\
\text { traditional } \\
\text { learning }\lfloor 28\rfloor \text { F2F }\end{array}$ \\
\hline Lucation & - & $\begin{array}{l}\text { Teachers have been using lab } \\
\text { rotation for many years, but } \\
\text { the difference is that this } \\
\text { model combines it with online } \\
\text { learning [12]. }\end{array}$ & $\begin{array}{l}\text { Students practice and } \\
\text { apply learning in school } \\
\text { during offline traditional } \\
\text { F2F learning [28] }\end{array}$ & 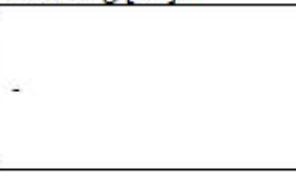 \\
\hline Example & - & $\begin{array}{l}\text { This model is common, but } \\
\text { students necd to compete with } \\
\text { other students to use the } \\
\text { computer lah [12]. There is } \\
\text { also a limit of time to stay in a } \\
\text { computer lab. }\end{array}$ & $\begin{array}{l}\text { Example: students listen } \\
\text { to tcachors outside of the } \\
\text { class time and complete } \\
\text { the homework during } \\
\text { class time with teachers } \\
\text { [12]. }\end{array}$ & - \\
\hline Differences & $\begin{array}{l}\text { Students rotate through } \\
\text { all stations and not just } \\
\text { the usual routines [25]. } \\
\text { [28]. }\end{array}$ & $\begin{array}{l}\text { It was found out that the lab } \\
\text { rotation model is ideal for } \\
\text { teachers who want to use } \\
\text { software to access the learning } \\
\text { materials or to repeat and } \\
\text { relearn a specific lesson [12]. } \\
\text { Students rotate out of their } \\
\text { classrooms to computer labs } \\
\text { to further their understanding } \\
\text { of the learning maller [28] } \\
\text { More supervision and careful } \\
\text { guidance are needed to } \\
\text { provent the students from } \\
\text { misusing the computer labs } \\
\text { [12]. }\end{array}$ & $\begin{array}{l}\text { Students will not be } \\
\text { passive learners because } \\
\text { it is more like an activity- } \\
\text { based learning method } \\
\text { [12]. } \\
\text { Students can control } \\
\text { their own time, place, } \\
\text { path and pace [28] } \\
\text { Alluws the teacher lo use } \\
\text { class lime efficiently to } \\
\text { enhance the } \\
\text { understanding of the } \\
\text { topic [12]. }\end{array}$ & $\begin{array}{l}\text { Students do not need } \\
\text { to rntate every } \\
\text { available station or } \\
\text { modality [25], [28] }\end{array}$ \\
\hline
\end{tabular}


Table (3) Students challenges in the online component of blended learning

\begin{tabular}{|c|c|c|}
\hline Inductive categories (codes) & Sub-categories & Articles \\
\hline Self-regulation Challenges (SRC) & $\begin{array}{l}\text { Procrastination } \\
\text { Online help-seeking challenge } \\
\text { Lack of self-regulation skills } \\
\text { Limited preparation before class } \\
\text { Poor time management skills } \\
\text { Improper utilization of online peer learning strategies }\end{array}$ & $\begin{array}{l}\text { (AlJarnah et al., 2018), (Broadbent, 2017), (Maycock } \\
\text { et al., 2018), (Chuang et al, 2018), (J. C. Y. Sun et al., } \\
\text { 2017) } \\
\text { (Broadbent, 2017), (Safford \& Stinton, 2016), (G. } \\
\text { Akçayır \& Akçayı,, 2018) } \\
\text { (J. C. Y. Sun et al., 2017), (Lightner \& Lightner.Laws, } \\
\text { 2016), (Chuang et al., 2018), (Cakiroglu \& Öztürk, } \\
\text { 2017) } \\
\text { (Long, Cummins, \& Waugh, 2017), (Xiso, Thor, Zheng, } \\
\text { Baek, \& Kim, 2018), (G. Akçayı \& Akçayr, 2018) } \\
\text { (Broadbent, 2017), (Zacharis, 2015) } \\
\text { (Broadbent, 2017) }\end{array}$ \\
\hline $\begin{array}{l}\text { Technological Literacy and } \\
\text { Competency Challenges (TLCC) }\end{array}$ & $\begin{array}{l}\text { Challenge in handling different user interfaces } \\
\text { Resistance to technology } \\
\text { Technological distraction from overly complex technology } \\
\text { Challenge of learning new technology by adult leamers } \\
\text { lack of technological competency } \\
\text { Students technological illiteracy } \\
\text { Adult learners' intimidation by learning technologies } \\
\text { Resistance to/or confusion about seeking appropriate } \\
\text { online help } \\
\text { Poor understanding of directions and expectations in } \\
\text { 'online learning' of blended learning. } \\
\text { Students perception of technology as a barriers to online } \\
\text { help seeking }\end{array}$ & $\begin{array}{l}\text { (P. Prasad, Maag, Redestowicz, \& Hoe, 2018) } \\
\text { (P. Prasad et al, 2018) } \\
\text { (P. Prasad et al., 2018) } \\
\text { (Salim et al., 2018), (Lightner \& Lightner-Laws, 2016) } \\
\text { (G. Akçayir \& Akçayur, 2018) } \\
\text { (Brown, 2016), (Kopcha, Orey, \& Dustman, 2015), } \\
\text { (Zacharis, 2015) } \\
\text { Safford and Stinton (2016) } \\
\text { Safford and Stinton (2016) } \\
\text { Safford and Stinton (2016) } \\
\text { (Kopcha et al., 2015) }\end{array}$ \\
\hline Students Isolation Challenges (SIC) & $\begin{array}{l}\text { Students alienation and isolation in online leaming } \\
\text { Students feeling of isolated and disinterested } \\
\text { Students problem with synchronous online communication } \\
\text { with the use of video projection, the microphones and } \\
\text { speakers } \\
\text { Remote students uncomfonable being center of attention }\end{array}$ & $\begin{array}{l}\text { Chyr, Shen, Chiang, Lin, and Tsai (2017) } \\
\text { Lightner and Lightner-Laws (2016) } \\
\text { Szeto and Cheng (2016) } \\
\text { (Bower, 2015) }\end{array}$ \\
\hline $\begin{array}{l}\text { Technological Sufficiency Challenges } \\
\text { (TSC) }\end{array}$ & $\begin{array}{l}\text { Insufficient access to technology } \\
\text { Inequality of technological accessibility } \\
\text { Outdated technology and lack of internet out of the class (in } \\
\text { online component) } \\
\text { Low bandwidth and slow processing speeds } \\
\text { Experience of technical difficulties in completing } \\
\text { assignments }\end{array}$ & $\begin{array}{l}\text { Gopalan, Bracey, Klann, and Schmidt (2018) } \\
\text { (G. Akcayir \& Akçayis, 2018) } \\
\text { Safford and Stinton (2016) } \\
\text { Safford and Stinton (2016) } \\
\text { (Henrie, Bodily, Manwaring, and Graham, 2015) }\end{array}$ \\
\hline $\begin{array}{l}\text { Technological Complexity Challenges } \\
\text { (TCC) }\end{array}$ & $\begin{array}{l}\text { Technological distraction from overly complex } \\
\text { technologies } \\
\text { Technological complexity } \\
\text { Challenge with longer videos for learning }\end{array}$ & $\begin{array}{l}\text { (P. Prasad et al., 2018) } \\
\text { (P. Prasad et al., 2018) } \\
\text { (Kim, Kim, Khera, and Getman, 2014) }\end{array}$ \\
\hline
\end{tabular}


Table (4) Teachers challenges in the online component of blended learning

\begin{tabular}{|c|c|c|}
\hline Inductive categories (Codes) & Sub-categories & Articles \\
\hline $\begin{array}{l}\text { Teachers Technological Literacy and Competency } \\
\text { Challenges (TTLCC) }\end{array}$ & $\begin{array}{l}\text { Challenge in making students aware of the online materials that are } \\
\text { available as part of their learning program } \\
\text { Challenge of training students in the use of online materials and } \\
\text { effective approaches to autonomous learning } \\
\text { Lack of technological competency } \\
\text { Lack of experience with creating instruction content on LMS platforms } \\
\text { Challenge in fostering an affective online learning climate } \\
\text { Challenge in learning a new technology to manage online courses } \\
\text { Technological tlliteracy } \\
\text { Resistance to technology } \\
\text { Teachers lack of confidence, the time, and willingness to learn the use } \\
\text { of technologies for teaching } \\
\text { Technological anxiety }\end{array}$ & $\begin{array}{l}\text { Cuesta Medina (2018) } \\
\text { Cuesta Medina (2018) } \\
\text { (G. Akçayır \& Akçayr, 2018) } \\
\text { Maycock et al. (2018) } \\
\text { Boelens et al. (2017a) } \\
\text { Cheng and Chau (2016) } \\
\text { Brown (2016) } \\
\text { (Hung \& Chou, 2015), } \\
\text { (Bower, 2015) } \\
\text { Lightner and Lightner-Laws } \\
\text { (2016) } \\
\text { (Brown, 2016) }\end{array}$ \\
\hline Online Video Challenges (OVC) & $\begin{array}{l}\text { Challenge in making quality online videos } \\
\text { Spending too much time and effort in creating online teaching } \\
\text { contents (videos) } \\
\text { Time consuming and difficulty in creating and editing an online video } \\
\text { content } \\
\text { Sharing of online videos is weighty with slow internet connections }\end{array}$ & $\begin{array}{l}\text { (G. Alcçayur \& Akçayur, 2018) } \\
\text { Long et al. (2017) } \\
\text { Brown (2016) } \\
\text { (Leo and Puzio, 2016) }\end{array}$ \\
\hline Technological Operational Challenges (TOC) & $\begin{array}{l}\text { Challenge in making students aware of online materials that are } \\
\text { available as part of their learning program } \\
\text { Challenge of training students in the use of online materials and } \\
\text { effective approaches to autonomous learning } \\
\text { Resolving technical difficulties is time consuming } \\
\text { Time consuming in designing and managing online course } \\
\text { Time wasting in troubleshooting technical problems } \\
\text { Managing students in both modes (online-synchronous \& online } \\
\text { students) is challenging to teachers. } \\
\text { Overly focused on remote students }\end{array}$ & $\begin{array}{l}\text { Cuesta Medina (2018) } \\
\text { Cuesta Medina (2018) } \\
\text { Leo and Puzio (2016) } \\
\text { Lightner and Lightner-Laws } \\
\text { (2016) } \\
\text { Bower (2015) } \\
\text { Bower (2015) } \\
\text { (Bower, 2015) }\end{array}$ \\
\hline Teachers Belief Challenges (TBC) & $\begin{array}{l}\text { Technology as a barrier to competency } \\
\text { Flipped classroom regarded as one of the barriers between technology } \\
\text { and teachers } \\
\text { Skepticism about the effectiveness of online activities in improving } \\
\text { learning }\end{array}$ & $\begin{array}{l}\text { Pilgrim et al. (2018) } \\
\text { Zengin (2017) } \\
\text { (Lightner and Lightner-Laws, } \\
\text { 2016) }\end{array}$ \\
\hline
\end{tabular}

Table (5) Educational institution challenges in the online component of blended learning

\begin{tabular}{|c|c|c|}
\hline Inductive categories (Code) & Sub-categories & Articles \\
\hline $\begin{array}{l}\text { Technological Provision Challenges } \\
\text { (TPC) }\end{array}$ & $\begin{array}{l}\text { High cost of producing electronic content } \\
\text { Cost of online learning technologies } \\
\text { Overly complex technology - distractions to students } \\
\text { Creation of tools that are flexible and compatible with other systems } \\
\text { Complexity of technology } \\
\text { Implementation of LMSs to suit students learning styles }\end{array}$ & $\begin{array}{l}\text { Dehghanzadeh and Jafaraghaee } \\
\text { (2018) } \\
\text { (G. Akçayir \& Akçayır, 2018) } \\
\text { (P. Prasad et al., 2018) } \\
\text { Brown (2016) } \\
\text { (Brown, 2016) } \\
\text { (Cheng and Chau, 2016) }\end{array}$ \\
\hline Teachers Training Challenges (TTC) & $\begin{array}{l}\text { Challenge in training teachers in the use of online materials and effective } \\
\text { approaches to autonomous use of online technologies for instruction }\end{array}$ & (Cuesta Medina, 2018) \\
\hline Other Challenges (OTC) & Lack of electronic technicians & $\begin{array}{l}\text { (Dehghanzadeh and Jafaraghaee, } \\
\text { 2018) }\end{array}$ \\
\hline
\end{tabular}


Singh (2003) refers to Badrul Khan's Octagonal blended e-learning to enables one to select appropriate ingredients. This frame work serves as a guide to plan, develop, deliver, manage, and evaluate blended learning programs. The framework has eight dimensions: institutional, pedagogical, technological, interface design, evaluation, management, resource support, and ethical (Figure 2).

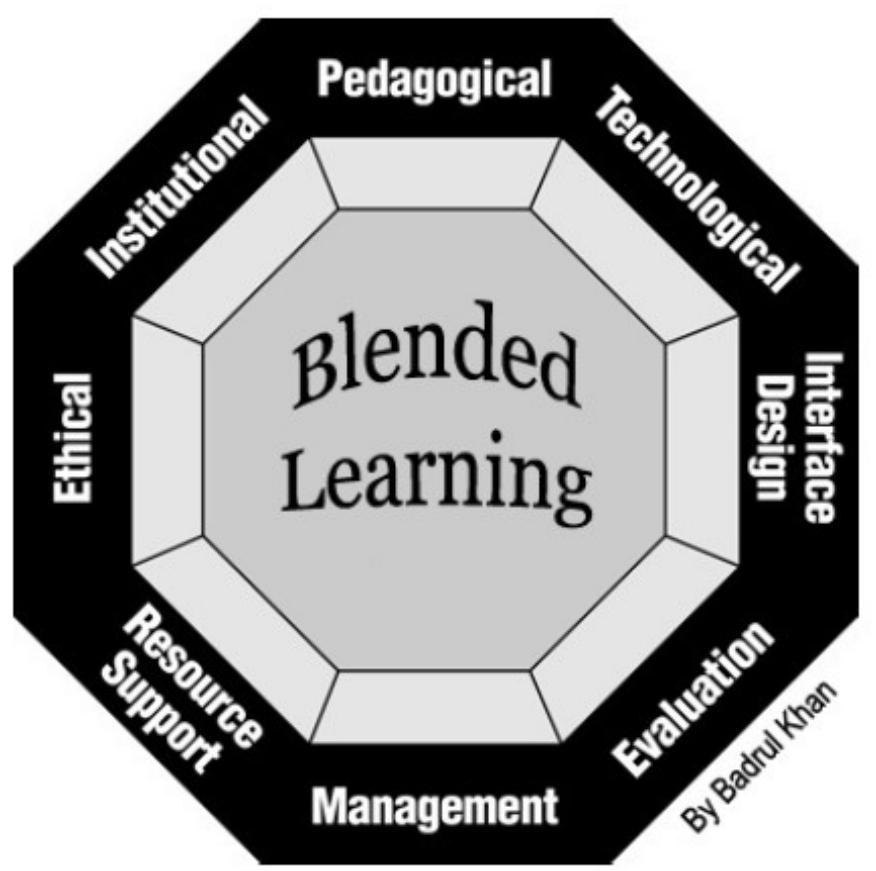

Figure (2) Khan's Octagonal Framwork.

Each dimension in the framework represents a category of issues that need to be addressed. The Institutional dimension addresses issues concerning organizational, administrative, academic affairs, and student services. The Pedagogical dimension is concerned with the combination of content that has to be delivered (content analysis), the learner needs (audience analysis), and learning objectives (goal analysis). The technological dimension address issues such as creating a learning environment and the tools to deliver the learning program. The Interface Design dimension addresses factors related to the user interface of each element in the blended learning program. The Evaluation dimension is concerned with the usability of a blended learning program. The Management dimension deals with issues related to the management of a blended learning program, such as infrastructure and logistics to manage multiple delivery types. The Resource Support dimension deals with making different types of resources (offline and online) available for learners as well as organizing them. Resource support could also be a counselor/tutor always available in person, via e- 
mail, or on a chat system. The Ethical dimension identifies the ethical issues that need to be addressed when developing a blended learning program such as equal opportunity, cultural diversity, and nationality should be addressed. Kayalar (2020) identified the various methods that may be useful to implement the following applications:

- Accessing tests and exams over the internet.

- Creating discussion boards online.

- Ensuring that source materials are available.

- Submitting preliminary work online.

- Providing instructor support to students.

- Using beneficial tools that help students organize information, review lesson instructions, and access summary information about the lessons requested.
- Creating virtual classes.

- Using e-mail and messaging effectively.

- E- Mailing students directly.

Concerning the evaluation of the blended learning, there are numerous frameworks and instruments for evaluating blended learning, although no particular one seems to be favored in the literature. This is partly due to the diversity of reasons for evaluating blended learning systems, as well as the many intended audiences and perspectives for these evaluations (Bowyer, 2017). However, it is important that any framework encompasses all aspects of the blended learning situation so that the interconnectedness is not lost. Bowyer (2017) proposed the following framework to achieve that.

Table (6) The framework for evaluating the blended learning

\begin{tabular}{|c|c|c|c|}
\hline Inel & Variable & Ellmentr & Mensultment \\
\hline \multirow[t]{2}{*}{ Situatbn } & Context & $\begin{array}{l}\text { Socibeconomic } \\
\text { Ethical } \\
\text { Letal } \\
\text { Cost } \\
\text { Acressiblity } \\
\text { Cultual } \\
\text { Ceograhicd } \\
\text { Support }\end{array}$ & 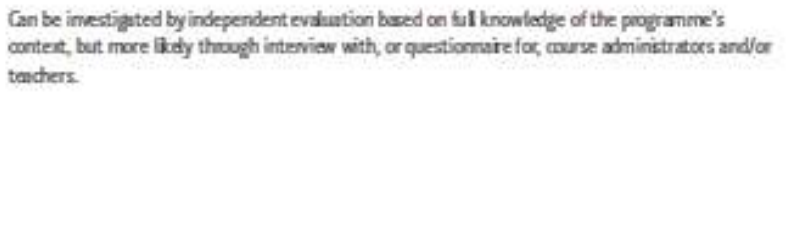 \\
\hline & Intoturtion & $\begin{array}{l}\text { Sepport } \\
\text { Adninistation }\end{array}$ & 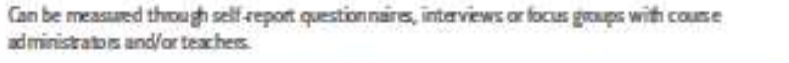 \\
\hline \multirow[t]{3}{*}{ Canre } & $\begin{array}{l}\text { Design and } \\
\text { plaring }\end{array}$ & 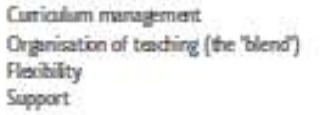 & 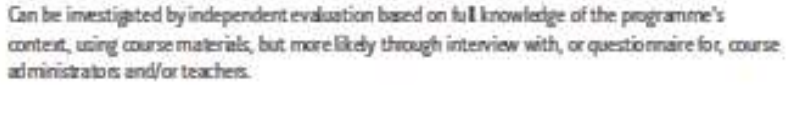 \\
\hline & $\begin{array}{l}\text { Contert } \\
\text { (ooline and } \\
\text { niclass) }\end{array}$ & $\begin{array}{l}\text { Nelevenos and scope } \\
\text { Qualing } \\
\text { Brext th of content }\end{array}$ & 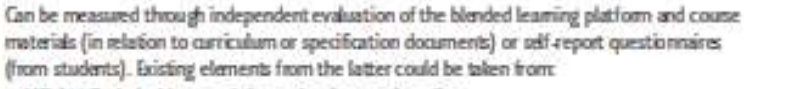 \\
\hline & & 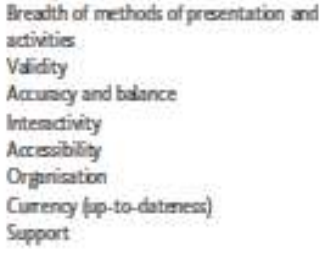 & 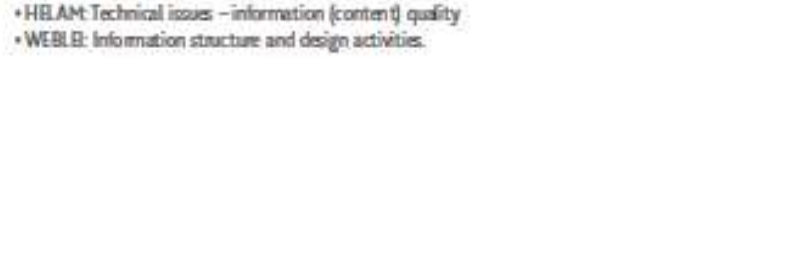 \\
\hline
\end{tabular}


Continue table (6) The framework for evaluating the blended learning

\begin{tabular}{|c|c|c|c|}
\hline Ined & Vaniable & Elementr & Mentulement \\
\hline & Assesament & $\begin{array}{l}\text { Divainy } \\
\text { Ft/ndevance } \\
\text { Support }\end{array}$ & 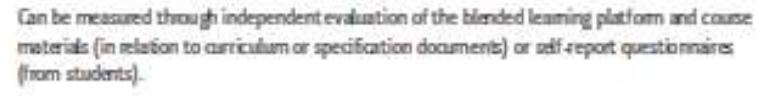 \\
\hline & Tedinoloty & 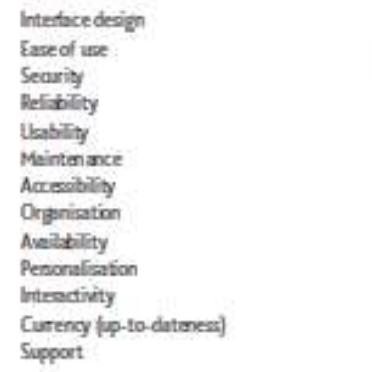 & 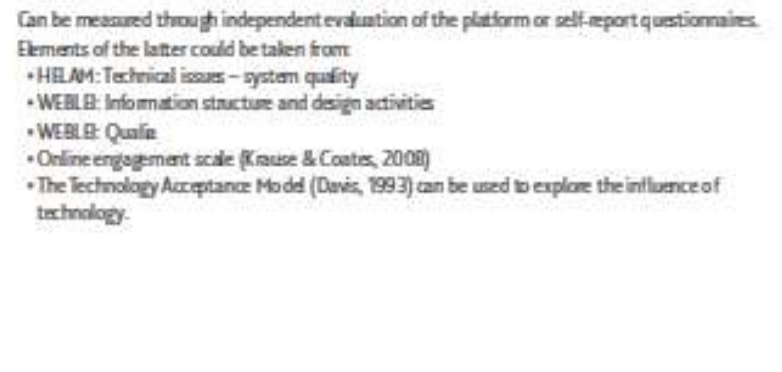 \\
\hline \multirow[t]{2}{*}{ Indvildal } & Teaches & 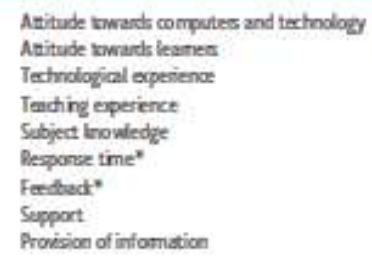 & 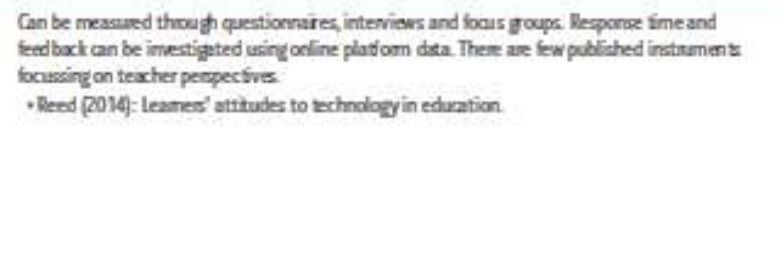 \\
\hline & Lesnes & 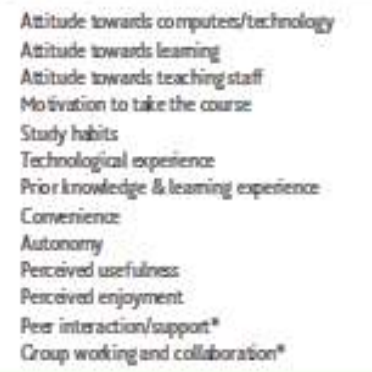 & 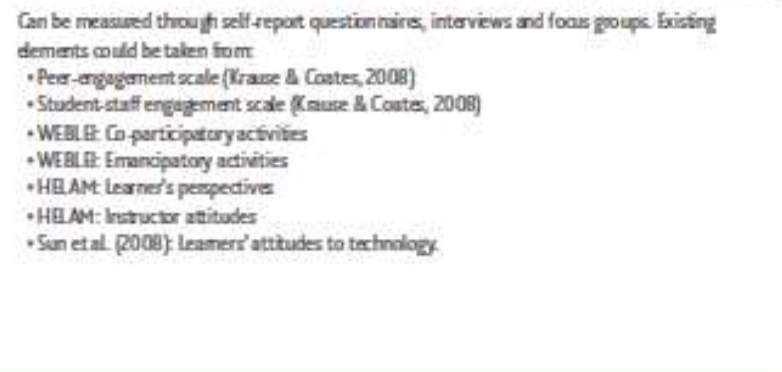 \\
\hline \multirow[t]{3}{*}{ Outcomes } & $\begin{array}{l}\text { Leamer } \\
\text { satisfaction }\end{array}$ & $\begin{array}{l}\text { With course (overall) } \\
\text { With learning } \\
\text { With teaching } \\
\text { Utility of course for future plans/education }\end{array}$ & $\begin{array}{l}\text { Can be measured through self-report questionnaires. Existing elements could be taken from: } \\
\text { - Sun et al. (2008): Perceived learner satisfaction } \\
\text { - NSS: Contribution of course to knowledge, skills and development. }\end{array}$ \\
\hline & $\begin{array}{l}\text { Student } \\
\text { engagement }\end{array}$ & $\begin{array}{l}\text { Psychological and cognitive engagement } \\
\text { Behavioural engagement } \\
\text { Emotional engagement }\end{array}$ & $\begin{array}{l}\text { Can be measured through self-report questionnaires. Behavioural engagement can be investigated } \\
\text { using online platform data. Existing elements could be taken from: } \\
\text { - Academic engagement scale (Krause \& Coates, 2008): psychological/cognitive engagenent } \\
\text { - Intellectual engagement scale (Krause \& Coates, 2008): psychological/cognitive engagement } \\
\text { - NSS: Elennents of behavioural and cognitive engagement. }\end{array}$ \\
\hline & $\begin{array}{l}\text { Course } \\
\text { outcomes }\end{array}$ & $\begin{array}{l}\text { Grades and marks } \\
\text { Online activity } \\
\text { Attendance } \\
\text { Drop out rates }\end{array}$ & Can be measured using the online platform data and teacher reports. \\
\hline
\end{tabular}

"Note: These elements entall the communication, interaction and collaboration aspect of the framework. 


\section{References}

Alammary, A., (2019). Blended learning models for introductory programming courses: A systematic review. PLoS ONE, 14(9): 1-26.

Ayob, N. F. S., Abd Halim, N. D., Zulkifli, N. N., Zaid, N. M. and Mokhtar, M., (2020). Overview of blended learning: the effect of station rotation model on students' achievement. Journal of Critical Reviews, 7(6): 320-326.

Bowyer, J., (2017). Evaluating blended learning: Bringing the elements together. Research Matters, 23:17-26.

Kachmarchyk, S., Khrystiuk, S., and ShanaievaTsymbal, L., (2019). Using blended learning technology in foreign language communicative competence forming of future international relations specialists. Revista Romaneascapentru Educatie Multidimensionala, 11(4): 84-99.

Kayalar, F., (2020). The Importance of blended learning approach during covid-19 pandemic all over the world. Proceedings of IAC in Vienna, 24-28.
Lotrecchiano, G. R., McDonald, P. L., Lyons, L., Long, T. and Zajicek-Farber, M., (2013). Blended learning: Strengths, challenges, and lessons learned in an Interprofessional Training Program. Matern Child Health Journal, 17: 1725-1734.

Marunić, G., (2015). Challenges of blended learning. Scientific proceedings of the international scientifictechnical conference "trans \& motauto, 3: 61-64.

Rasheed, R. A., Kamsin, A. and Abdullah, N. A., (2020).Challenges in the online component of blended learning: A systematic review. Computers \& Education, 144: 1-17.

Singh, H., (2003). Building effective blended learning programs. Journal of Educational Technology, 43 (6): 51-54.

Titov, S., Kurilov, A. Titova, N. and Brikoshina, I., (2019). Integrative assessment framework in blended learning.TEM Journal, 8 (3): 768-774. 